\title{
Urban household cooking energy choice: an example of Bauchi metropolis, Nigeria
}

\author{
Danladi Yusufu Bisu', Aondoyila Kuhe ${ }^{2^{*}}$ and Humphrey Aondover lortyer ${ }^{2}$
}

\begin{abstract}
Background: The use of traditional energy sources such as wood, animal dung and agricultural residue by households has been in practice since time immemorial. This has however been identified as a cause of environmental problems such as excessive deforestation and the cause of the premature death of about 4.3 million people yearly; it caused the death of about 396,000 people in Sub-Saharan Africa, where Nigeria is located, in 2002. It was also responsible for $2.7 \%$ of the global burden of disease in that year. The reasons for fuel choice are different for different locations. This paper presents the results of a study in the factors affecting the cooking energy choice of households in Bauchi metropolis, North-east Nigeria. The aim of the study was to provide site-specific information that will aid the formulation of an effective energy policy which will result in safer and sustainable energy behaviour among households in Bauchi and Nigeria as a nation. The study therefore determined the cooking energy consumption pattern of the household and whether it follows the energy ladder model and also determined the factors that influence cooking energy choice.

Methods: Two-step random sampling was used along with a semi-structured questionnaire to collect data. Descriptive statistics, $T$ test and regression analysis were used to analyse the data through the help of Microsoft excel ${ }^{\mathrm{TM}}$ and SPSS.

Results: The results show that biomass fuel is still being used heavily while the use of LPG has improved. Electricity and solar energy are only used by households as secondary cooking energy. The fuel use pattern is characterized by multiple fuel use, conforming more to the fuel stacking hypothesis than energy ladder hypothesis. Change in household size, dwelling ownership status, change of season, income, level of education, dwelling location, availability and affordability are the factors that were found to influence household cooking energy choice.

Conclusions: This paper concludes that the heavy use of biomass for cooking in Bauchi metropolis is not environmentally healthy and requires serious attention. The major recommendation of the study is that policies encouraging the availability and use of efficient and environmentally friendly energy sources should be formulated and implemented.
\end{abstract}

Keywords: Sustainability, Energy choice, Consumption pattern, Household, Cooking energy

\section{Background}

Energy is a key ingredient for social, economic and industrial development of every nation [1-4]. However, access to modern, affordable and reliable energy services is an enormous challenge facing the African continent, particularly Nigeria [5]. African Development Bank Group [6] reported that the national electricity access and per capita consumption for Nigeria is only $48 \%$ and

\footnotetext{
* Correspondence: amkuhe@uam.edu.ng

${ }^{2}$ Department of Mechanical Engineering, Federal University of Agriculture,

Makurdi, Nigeria

Full list of author information is available at the end of the article
}

$149 \mathrm{kWh}$, respectively. This is less than for Senegal (56 \% and $187 \mathrm{kWh} /$ person), Cote d'Ivoire (59.5 \% and $212 \mathrm{kWh} /$ person), Ghana (72 \% and $344 \mathrm{kWh} /$ person) and Maroc (98.96 and $826 \mathrm{kWh} /$ person), who have far less amounts of energy resources than Nigeria. This energy poverty is experienced more by Nigerian rural dwellers that have an access rate of less than $30 \%$. More so, electricity supply in the country is characterized by frequent power outages, which has rendered the 'public supply a standby source as many consumers who cannot afford irregular and poor quality service substitute more 
expensive captive supply alternatives to minimize the negative consequences of power supply interruptions on their production activities and profitability', causing about $20 \%$ of the investment in industrial projects to be allocated to mostly more expensive and alternative sources of electricity [7]. This acute shortage and irregular supply of clean energy sources has also caused more households in Nigeria to depend on traditional energy sources such as wood, animal dung and agricultural residue causing personal health and environmental problems such as excessive deforestation [8], estimated at 300,000 ha per year.

In Nigeria, about $65 \%$ of the total energy consumption is taken by the household, probably due to under development of the industrial sector. Cooking accounts for about $91 \%$ of the total domestic energy consumption [3]. Despite the abundance of renewable, environmentally friendly energy sources [9], about three billion people worldwide still use solid fuels for their basic needs which include cooking, boiling water and space heating. Data shared by [10] shows that the use of biomass as fuel has been increasing, while the use of higher fuels decrease at a highly unacceptable rate. It shows that between 1980 and 2004, the use of firewood increased from 47.6 to $70.8 \%$, while the use of kerosene and electricity declined from 49 to $26.6 \%$ and from 2.6 to $0.5 \%$, respectively. The use of liquefied petroleum gas (LPG) has also remained low (1.1\%) through the period. The problem seems to be worsening as about $86 \%$ of households still depend on fuel wood as their source of energy [3]. Indoor cooking using solid fuels have been described as a 'dangerous activity' which is responsible for the premature death of about 4.3 million people yearly [11]. It was responsible for the death of about 396,000 people in Sub-Saharan Africa, where Nigeria is located, in 2002. It was also responsible for $2.7 \%$ of the global burden of disease in that year $[12,13]$.

This calls for interventions that will facilitate changing the energy consumption behaviour of households and individuals towards minimal household health risk and environmental sustainability. International organizations such as the United Nations (UN), World Health Organization (WHO) and the World Bank are making frantic efforts to change the trend. The UN has launched the Sustainable Energy for All (SE4ALL) campaign with the aim of ensuring universal access to clean, safe and modern energy services; doubling the global rate of improvement in energy efficiency and doubling the share of renewable energy in the global energy mix by 2030 $[14,15]$. The World Bank has recently launched the 'Africa Clean Cooking Energy Solutions' to promote dissemination and adoption of clean cooking solutions and the 'East Asia and Pacific region's Clean Stove Initiative' (CSI) to scale up access to advanced cooking stoves for rural poor households through country-specific technical assistance and a regional knowledge-sharing and cooperation forum [14]. These efforts have, however, not yielded the desired result as most households in Africa still depend on inefficient energy sources [16].

For these efforts to yield useful results, research is required, as a first step, into the factors that influence energy choice and consumption behaviour of households, especially due to the fact that household fuel consumption varies tremendously across geographic regions due to disparities in availability of different amenities and energy sources $[17,18]$.

Several theories have been used in attempts to explain household energy choice. One theory that has been used extensively in studying household energy choice is the 'energy ladder model'. The energy ladder model classifies household fuels into three groups: traditional, transition and advanced fuels. The model assumes that lowincome households would use the traditional fuels until their socio-economic status improves and then they will rationally switch completely to the transition fuels. According to this theory, a further increase in household income will then lead to another rational transition to the advanced fuels $[19,20]$. In other words, the energy ladder model attributes household fuel choice and transition to only income. It assumes that households will ascend the imaginary ladder in a somewhat linear progression pattern, by switching completely to higher level fuels as their income improve [21, 22]. However, this model has been criticized heavily for its lack of consideration of the intricate interactions that characterize energy transition, family differences, cultural factors, personal preferences, etc.

Consequent upon the observed weaknesses of the 'energy ladder' model, alternative models have been proposed. One of such models is the 'fuel stacking' model proposed by [23]. This model assumes that household energy use patterns depend on several factors (not only income) which could be social, economic, cultural, or even personal preferences. Therefore, rather than transiting linearly to cleaner fuels, households tend to increase the number of fuels used without actually abandoning the old ones [24]. The fuel stacking model has been found to be true by many researchers such as [10], [14] and [25], who found fuel stacking to be practiced more by households with higher income. In other words, households increased the number of fuels they used as their income increased. 'Such behaviour is associated with the fact that while households were more likely to afford to buy additional cooking stoves if new fuel types required them, there were also various other reasons to do so, including preferences for a particular fuel type used to cook a particular type of food, for a particular 
time or occasion, for convenience, or due to uncertainty about the supply of a fuel type' [26].

Growing concerns over limitations in the ability of individual consumer characteristics to explain variations in consumer behaviour has necessitated appeals to examine situational influences on behaviour. It has been argued that situational factors may account for more variance than actor-related variables, hence the need to consider both individual and situational factors in explaining consumer behaviour $[27,28]$. This study therefore investigates the factors which influence households' choice of their cooking energy. Energy in this case refers to all energy types, both renewable and non-renewable. The aim is to provide site-specific information that will aid the formulation of an effective energy policy which will result in safer and sustainable energy behaviour among households in Bauchi and Nigeria as a nation. Specifically, the study attempts to answer the following research questions:

- What is the cooking energy consumption pattern of households in Bauchi metropolis?

- Does the cooking energy consumption pattern of households in Bauchi metropolis follow the energy ladder hypothesis?

- What are the factors that influence cooking energy choice of households in Bauchi metropolis?

\section{Methods}

\section{Study area and data}

Bauchi metropolis is the largest city in Bauchi state of the North-east geopolitical zone of Nigeria. It is the state capital and the capital of Bauchi Local Government Area. It is located on latitude 10.3098 and longitude 9.8452. The city has a population of 316,173 and a land mass of $3687 \mathrm{~km}^{2}$. In the context of this research, Bauchi metropolis was considered to include seven suburban residential areas namely, Rafin-Zurfi, Birshi, Kafin-Tafawa, Wuntin-Dada, Miri, Turwun, Inkil and Gudum. A two-step stratified random sampling was employed to collect data. The study utilizes a crosssectional data collected in 2014/2015 through personal interview of 100 households which were randomly selected from the city and seven suburban residential areas. The distribution of respondents is presented in Table 1.

\section{Data collection and analysis techniques}

The instrument used for data collection is a semistructured questionnaire consisting of questions on household demographics, fuel and cooking technology choice, fuel budget, awareness of harmful effects of using traditional fuels and technologies and the adoption of clean energy and modern technologies for cooking. The
Table 1 Distribution of respondents

\begin{tabular}{lll}
\hline Residential area group & $\begin{array}{l}\text { Sample residential } \\
\text { area }\end{array}$ & $\begin{array}{l}\text { Number of } \\
\text { respondents }\end{array}$ \\
\hline Barracks & Yelwa police barracks & 5 \\
& Township police barracks & $7(25)$ \\
& Shada-wanka cantonment & 8 \\
& School of armour & 5 \\
Suburbs & Wuntin-Dada & 5 \\
& Kafin-Tafawa & $8(25)$ \\
& Turwun & 7 \\
Gov't quarters/housing & Old Gil & 5 \\
estates & State low-cost & 8 \\
& Tambari housing estate & $5(25)$ \\
& Tafawa-Balewa housing estate & 7 \\
General township & Nasarawa-Jahun & 8 \\
& Dutsen-tanshi & $5(25)$ \\
& Igbo-quarters & 7 \\
Gotal number of respondents & 5 \\
\hline
\end{tabular}

questionnaire was administered to either household heads or their spouses because they are responsible for cooking energy decisions. If these two were not available, the questionnaire was administered to a female member of the household who was up to 15 years of age and usually took part in cooking energy decisions. This is to ensure that information obtained was dependable and from reliable sources. Trained research assistants assisted in the administration of the questionnaires. Face-to-face method of questionnaire administration was used.

Microsoft Excel $^{\text {Tw }}$ and Statistical Package for Social Sciences (SPSS) were used to analyse the data. $T$ test was used to compare variables, while multi-variable linear regression analysis was used to determine relationships between variables. The Microsoft Excel ${ }^{\mathrm{Tm}}$ was used for descriptive statistical analysis.

\section{Results and discussion \\ Results}

Socio-economic characteristics of respondents

The distribution of the respondents according to gender is $61.3 \%$ male and $38.7 \%$ female. The mean family size of the respondents is $7(\mathrm{~S} . \mathrm{D}=3.67)$. With regard to the ownership status of households' dwelling, $44.7 \%$ were personally owned while $32.1 \%$ were rented. The annual income distribution of households is shown in Fig. 1, ranging from $\mathrm{N} 36,000(\$ 150)$ to $\mathrm{N7}, 200,000(\$ 30,000)$.

Based on their levels of education, the respondents are distributed as shown in Fig. 2. For the households, 


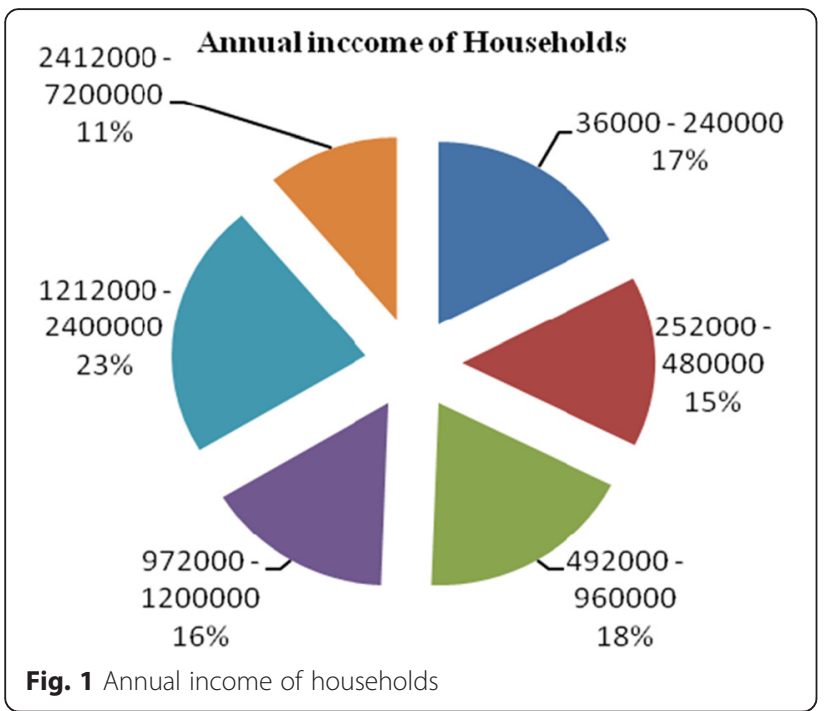

$15.3 \%$ have attained post graduate education; $41.6 \%$ have acquired tertiary education up to undergraduate level, while $35.4 \%$ had primary education and $7.7 \%$ are illiterate.

Figure 3 shows the access and consumption rates of the various cooking energy types available to households in Bauchi metropolis. It shows that $100 \%$ of respondents have access to the sun, since it is naturally available; $92.6 \%$ of the households have their dwellings connected to the national grid. The energy type with least access rate is LPG (52.7\%), despite the abundance of petroleum resources in Nigeria. It should be noted that the low availability (absence of energy when needed due to inconsistent supply (as shown in Figs. 4 and 5)) of electricity may be the reason for its low consumption rate by households (7.29\%).

Solar energy has the least consumption rate $(1 \%)$ probably due to lack of possession of appropriate technology (e.g. solar cookers, as they are not readily available in the market), while only $26 \%$ of households use LPG for cooking. Paired sample $T$ test analysis shows that there is a significant difference between access and consumption rates of households' cooking energy. It gives a $t$ value of 3.031 and a $p$ value of 0.029 . More so, a paired sample correlation analysis gives a correlation coefficient of -0.235 , signifying very low and negative correlation between the access and consumption rates. This shows that in Bauchi metropolis, Nigeria, access to an energy source (being connected to the grid, for example) does not necessarily lead to high consumption rate of such energy. For example, accessibility of electricity does not translate into availability, as shown in Fig. 4, where electricity supply is so inconsistent that only $6 \%$ of households have electricity available to them between 5 and 7 days per week. More so, most of the respondents (73\%) only have electricity available for $1-5 \mathrm{~h}$ per day, while only a mere $1 \%$ of respondents can boast of enjoying electricity supply for 16 to $20 \mathrm{~h}$ per day (Fig. 5); the sun is accessible by all, but only few $(1 \%)$ have the means to convert it into useful energy for cooking, probably due to scarcity of appropriate appliances.

\section{Prices of cooking energy}

The prices of cooking energy were determined for the cooking energy types considered in this study thus: wood N7 (\$0.03)/kg; charcoal N35 $(\$ 0.15) / \mathrm{kg}$; kerosene $\mathrm{N} 120 \quad(\$ 0.5) / \mathrm{L} ; \quad$ LPG N280 $(\$ 1.2) / \mathrm{kg}$ and electricity $\mathrm{N} 43.91(\$ 0.18) / \mathrm{kWh}$. None of the energy types is subsidized, and there is no incentive for consuming any of the energy types.

\section{Cooking energy consumption pattern}

The primary and secondary cooking energy consumption patterns for households in Bauchi metropolis are

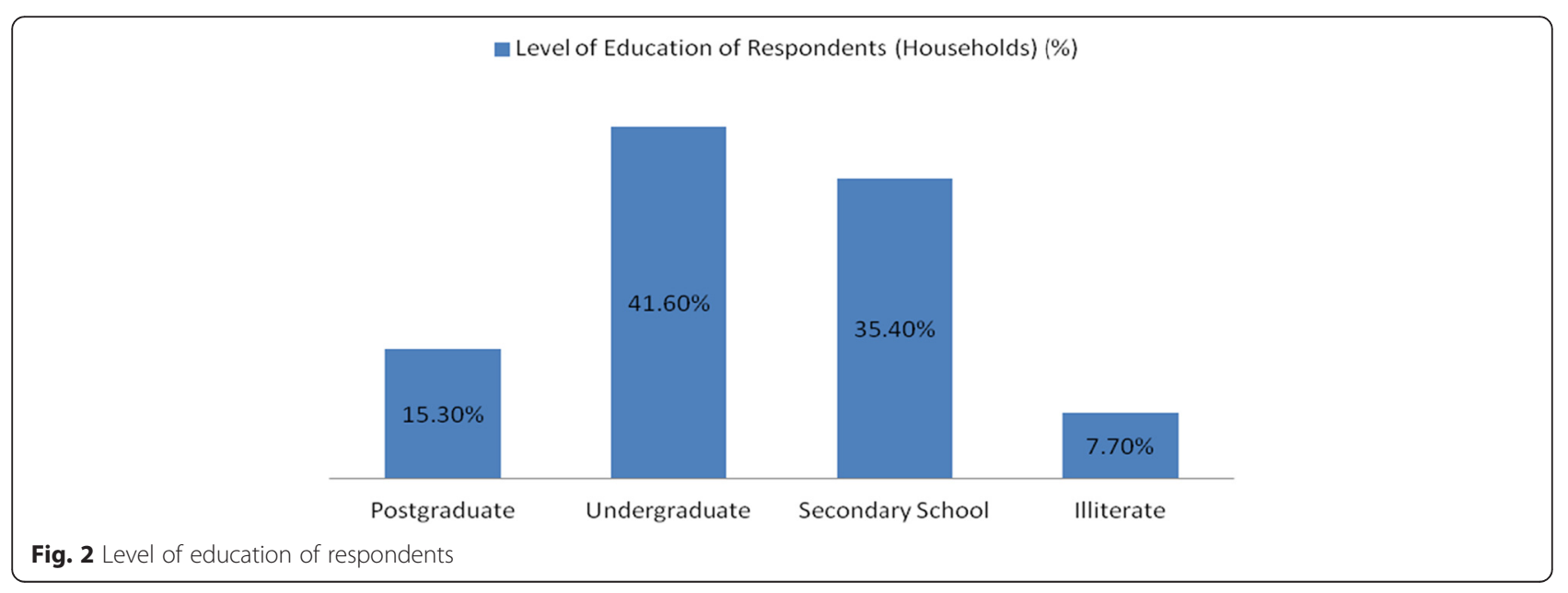




\section{access Rate $(\%) \quad$ Consumption Rate $(\%)$}

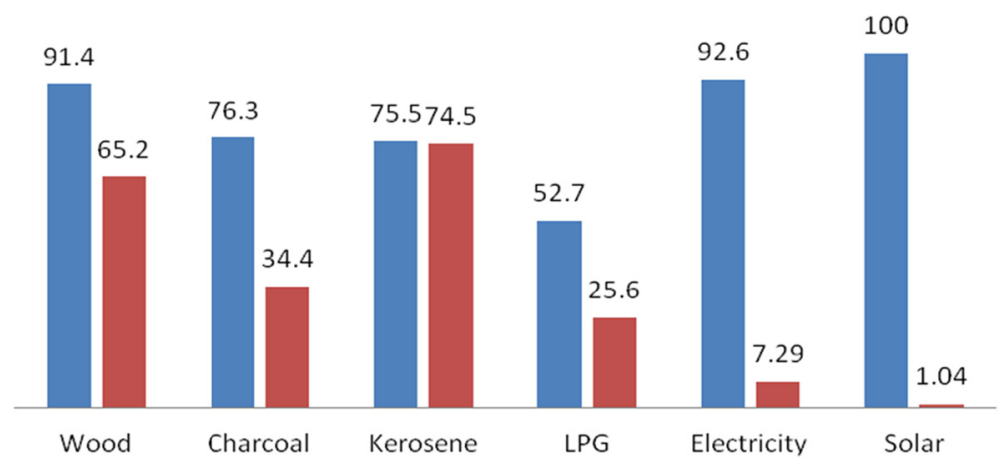

Fig. 3 Households' cooking energy access and consumption rate

shown in Fig. 6. The primary cooking energy consumption pattern shows that kerosene has the highest consumption rate of $41 \%$ followed by wood $35 \%$. LPG is the next with utilization rate of $24 \%$, followed by charcoal $(20 \%)$. The households do not use electricity or solar energy as primary cooking energy.

For the secondary cooking energy consumption pattern, the use of wood, charcoal and kerosene increased to 36,23 and $47 \%$, respectively, while the use of LPG dropped to $8 \%$. Of the households, 7 and $1 \%$ use electricity and solar energy, respectively, as secondary cooking energy. $T$ test result shows that there is no significant difference between the primary and secondary cooking energy consumption patterns at $95 \%$ confidence level; it gives a $t$ value of -0.135 and $p$ value of 0.898 . This means that consumption patterns of households' primary and secondary cooking energy are statistically the same; the variation is negligible.

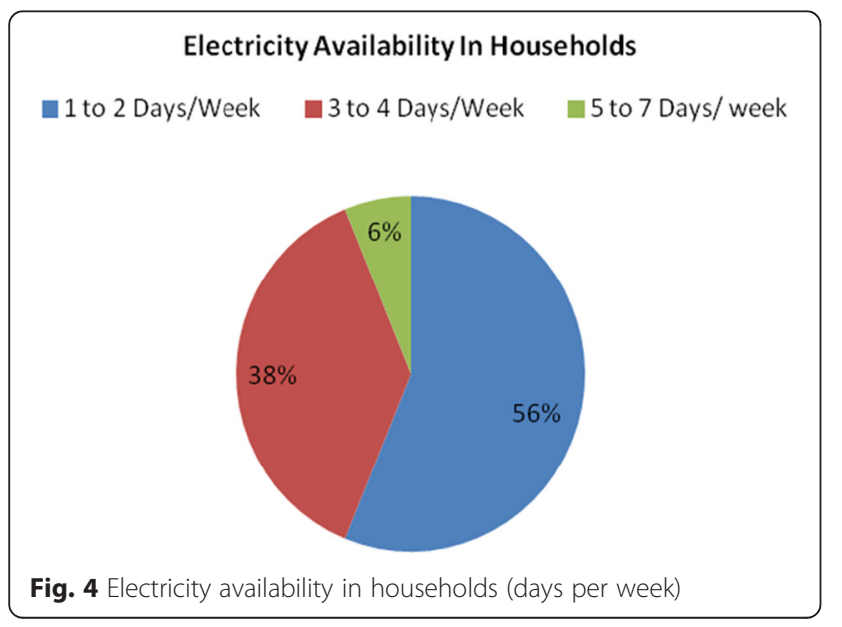

\section{Households' cooking energy mix}

Fifteen per cent of the respondents use only one fuel, while $85 \%$ use multiple fuels. The maximum number of fuels combined in a household is 4 . Table 2 shows the details of cooking energy mix for households.

\section{Factors affecting households' cooking energy choice}

Factors which influenced respondents' choice of their cooking energy were compiled and analysed as shown in Fig. 7.

Estimated models have been generated through the multi-variable linear regression analysis for the consumption of each of the primary fuels considered in this study. The energy sources (solar energy and electricity) which are being used only as secondary energy have been left out of this analysis, since they are not of primary concern to the households. The result shows that while change in household size (Chs), dwelling ownership status (DOS), change of season $(C S)$, income (Ic), level of education (Ed), dwelling location $(D L)$, availability $(A v)$ and affordability $(A f)$ are influential to households' fuel choice, type of food,

\section{Electricity Availability In Households}

$\square 1$ to 5 Hours per Day $\square 6$ to 10 Hours per Day $\square 11$ to 15 Hours per Day $\square 16$ to 20 Hours per Day $\square 21$ to 24 Hours per Day

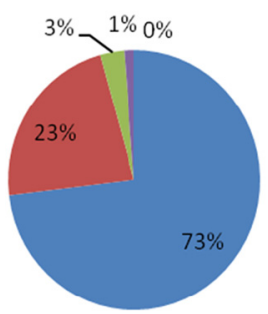

Fig. 5 Electricity availability in households (hours per day) 


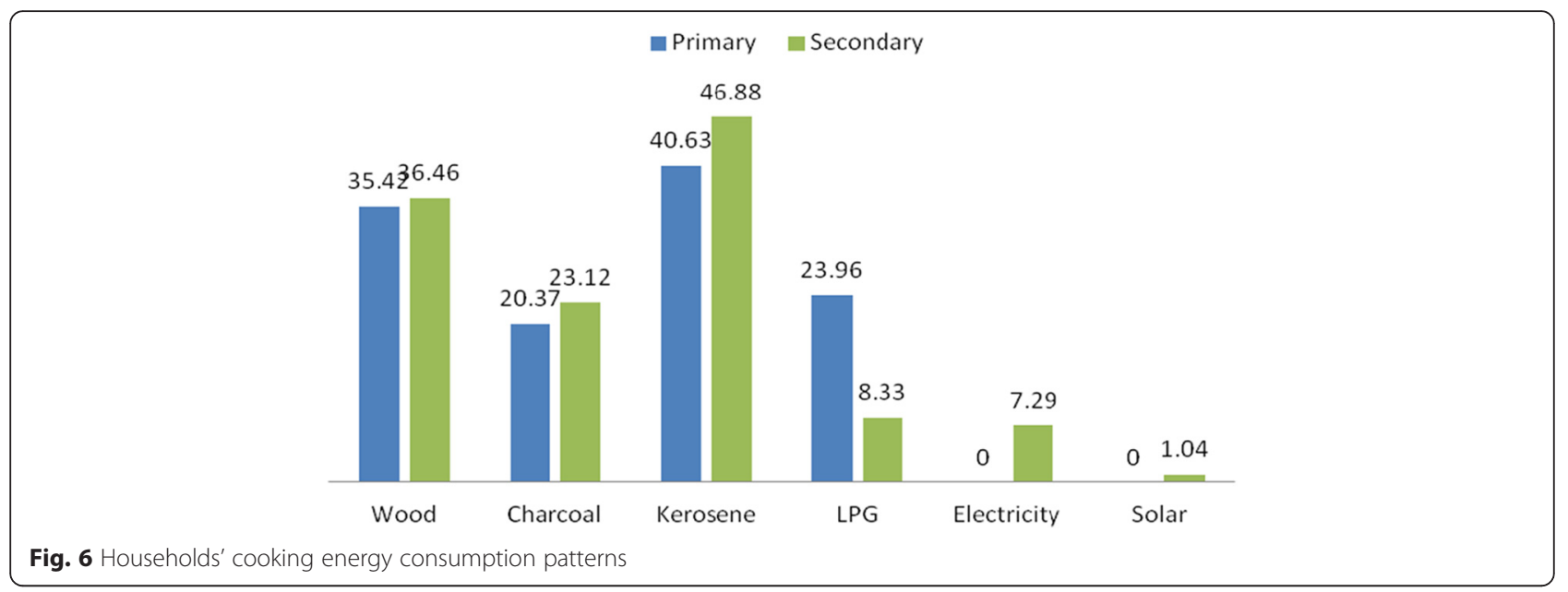

taste of food, quantity of food, land lord's rules, ease of use, fastness, scarcity of primary fuel and gender have no significant influence on households' fuel choice. Equations (1), (2), (3) and (4) represent the estimated fuel consumption models for wood $(W)$, charcoal $(C)$, kerosene $(K)$ and LPG $(L)$, respectively.

$$
\begin{gathered}
W=42.788+29.488 C h s+17.499 D O S-322.748 C s \\
-14.082 I c-13.398 E d
\end{gathered}
$$

Equation (1) shows that an increase in the family size of a household in the study area will result in an increase of $29.488 \mathrm{~kg}$ of wood, while a change in the dwelling ownership status of a single household from rented to personally owned dwelling in the study area will result

Table 2 Households' fuel mix

\begin{tabular}{lc}
\hline Fuel mix & Population (\%) \\
\hline Wood only & 32.2 \\
Kerosene only & 20.83 \\
Electricity only & 0.00 \\
Charcoal only & 17.09 \\
LPG only & 7.25 \\
Solar only & 0.00 \\
Wood + kerosene & 17.71 \\
Wood + kerosene + charcoal & 3.21 \\
LPG + kerosene + solar & 8.21 \\
LPG + kerosene & 1.04 \\
LPG + electricity & 4.27 \\
Kerosene + electricity + wood & 4.17 \\
LPG + wood + charcoal & 3.13 \\
LPG + wood & 5.21 \\
Wood + LPG + kerosene + charcoal & 10.42 \\
\hline
\end{tabular}

in an increase of $17.499 \mathrm{~kg}$ of wood (Fig. 10). However, when the season changes from dry to rainy season, when a households' income increases and when the education level of a households' cooking energy decision maker increases, then wood consumption will decrease by $322.748,14.082$ and $13.398 \mathrm{~kg}$, respectively (Figs. 9 and 12).

$$
C=7.601+1.837 D l-10.002 A v
$$

Equation (2) shows that charcoal consumption is affected by only two factors, dwelling location and availability. It shows that if a household in the study area changes location from a barracks or government quarters/housing estates to a residential area in the suburb or general township, then charcoal consumption will increase by $1.837 \mathrm{~kg}$ (Fig. 11). However, a decrease in the availability of charcoal will result in a decrease in its consumption by $10.002 \mathrm{~kg}$.

$$
\begin{aligned}
K= & -0.699+7.654 A v+3.651 C s-5.713 C h s \\
& -2.348 D O S
\end{aligned}
$$

Equation (3) shows that an increase in the availability of kerosene in the study area will result in a $7.654 \mathrm{~L}$ increase in its consumption. This is important because of the unsteady nature of kerosene supply. A change from dry to rainy season will also increase kerosene consumption by $3.651 \mathrm{~L}$. However, as the size of one household increase, kerosene consumption drops by $5.713 \mathrm{~L}$ as it becomes too expensive for the large family (so they tend to switch to cheaper fuels). Kerosene consumption also decreases by $2.348 \mathrm{~L}$ with one household personally owning its dwelling. Personal ownership of a dwelling gives the households' freedom to use any fuel of their choice. More so, the household is likely to have more 


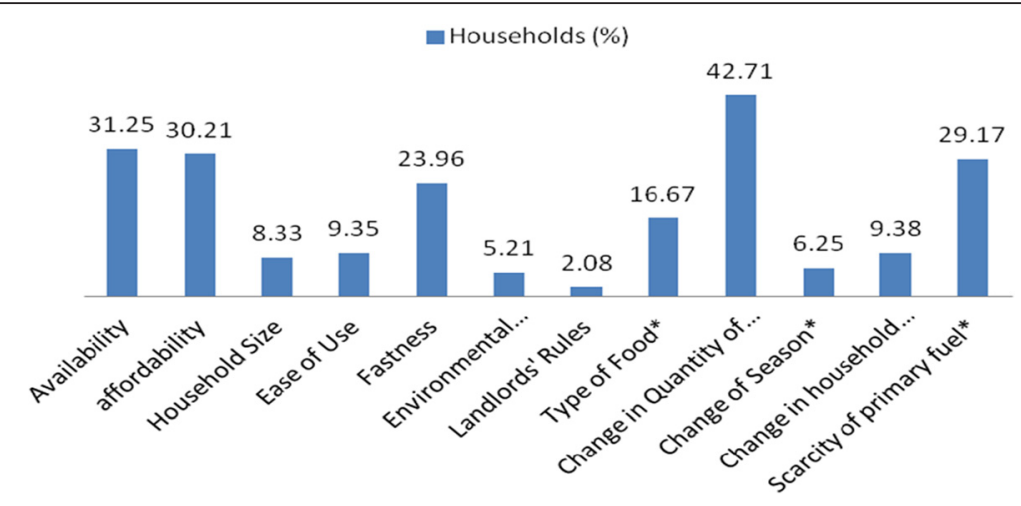

Fig. 7 Factors affecting cooking energy choice

space available for external kitchen construction and for storage of bulky fuels like wood and charcoal.

$$
L=4.276+1.286 A f-3.003 A v-1.116 C h s
$$

Equation (4) shows that LPG consumption is increased by $1.286 \mathrm{~kg}$ when one household in the study area is able to afford to acquire it and appropriate technology to use it for cooking. This means that an improvement in the economic status of a household increases its capacity to acquire the technology for LPG use. For example, Fig. 12 shows how LPG consumption increases with increase in households' income. However, if the LPG availability decreases, its consumption will reduce by $3.003 \mathrm{~kg}$ due to scarcity. In this case, households are forced to turn to alternative fuels. The equation also shows that an increase in household size will also result in the decrease in LPG usage by $1.116 \mathrm{~kg}$ as cooking which it becomes uneconomical for the family.

The influences of gender, level of education, dwelling ownership status, dwelling location and income on the cooking energy choice of households were further analysed as presented in Figs. 8, 9, 10, 11 and 12. These provide more explanation on the nature of influence of each of the factors on household fuel choice. More so, they

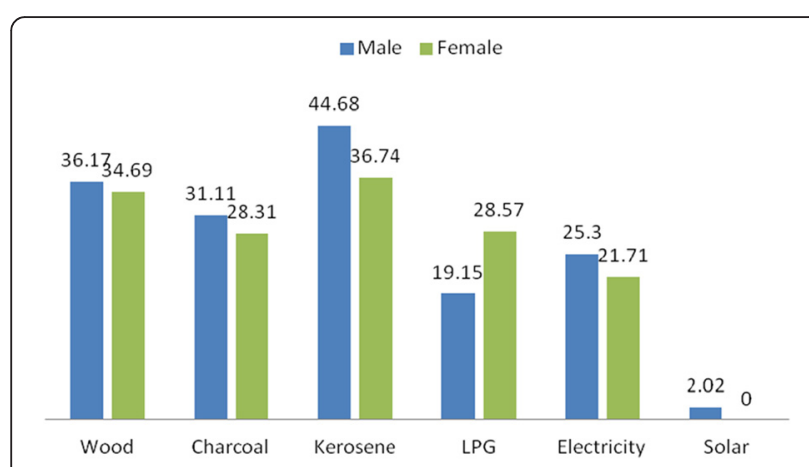

Fig. 8 Influence of gender on cooking energy choice provide information on the fuel switching behaviour of the households.

\section{Influence of gender on cooking energy choice}

Figure 8 gives a graphical description of the influence of gender on the choice of cooking energy by respondents. The result shows that more males (36\%) prefer wood than the female (35\%). In charcoal utilization, males (31 \%) exceed females (28\%). Forty-five per cent of males and $37 \%$ of females use kerosene. However, only $19 \%$ males and $29 \%$ females use LPG for cooking. The results further shows that while $25.3 \%$ of females use electricity for cooking, only $22 \%$ of males use it. Finally, solar energy is only used by $2 \%$ of males. $T$ test gives a $t$ value of 0.443 against a $p$ value of 0.681 , indicating that there is no significant difference in the cooking energy preferences of males and females. In other words, gender does not really have any significant influence on cooking energy choice of households in the study area.

\section{Influence of level of education on households' cooking energy choice}

Figure 9 shows the relationship between cooking energy choice and respondents' level of education. The result

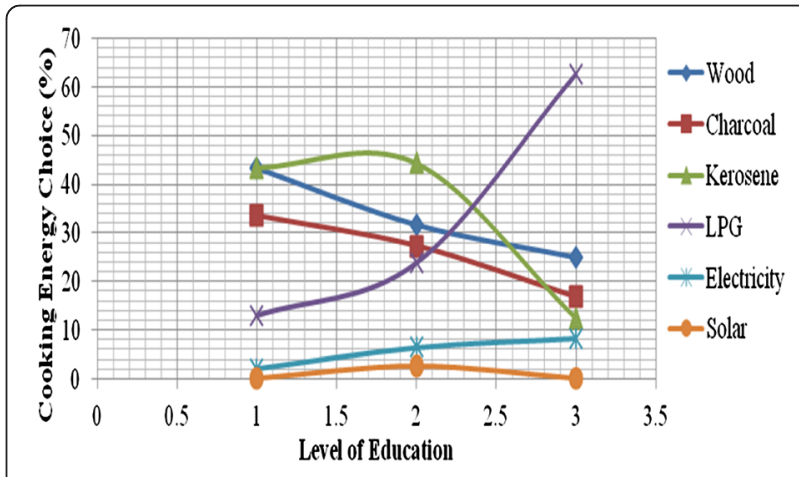

Fig. 9 Influence of education on households' cooking energy choice 


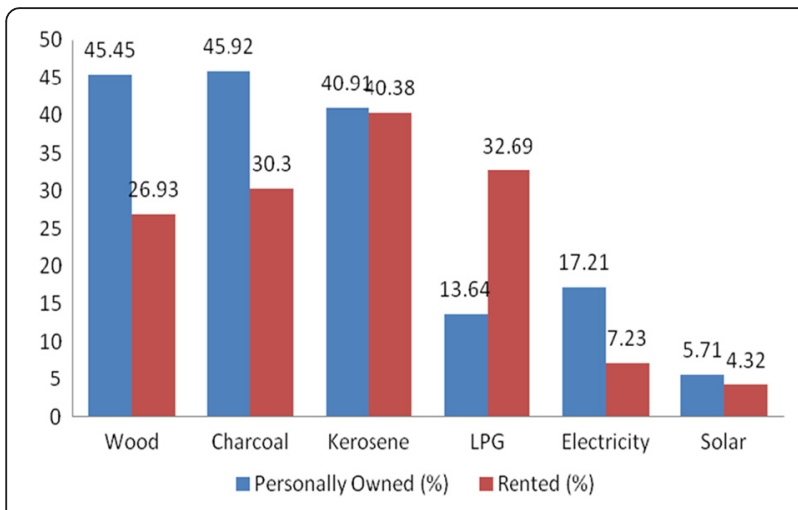

Fig. 10 Influence of households' dwelling ownership status on cooking energy choice

shows that while wood, charcoal and kerosene utilization decline with increasing level of education, electricity utilization increases gradually with rising level of education, while LPG utilization rises sharply with increase in the level of education. Solar energy utilization tends to rise with level of education and then drops to zero. Regression analysis shows that education is strongly correlated with cooking energy choice in the households with $97.8 \%(R=0.978)$ of variations in the regressors explained.

\section{Influence of households' dwelling ownership status on cooking energy choice}

Figure 10 shows a graphical representation of the influence of dwelling ownership status of households on their cooking energy choices. $T$ test result gives a $t$ value of 0.808 and a $p$ value of 0.045 , showing that there is a significant difference between the cooking energy consumption patterns of households living in personally owned dwellings and those in rented dwellings. The difference is that those in rented dwellings tend to use higher fuels (such as kerosene and LPG) because they are compact and will not require large space for storage,

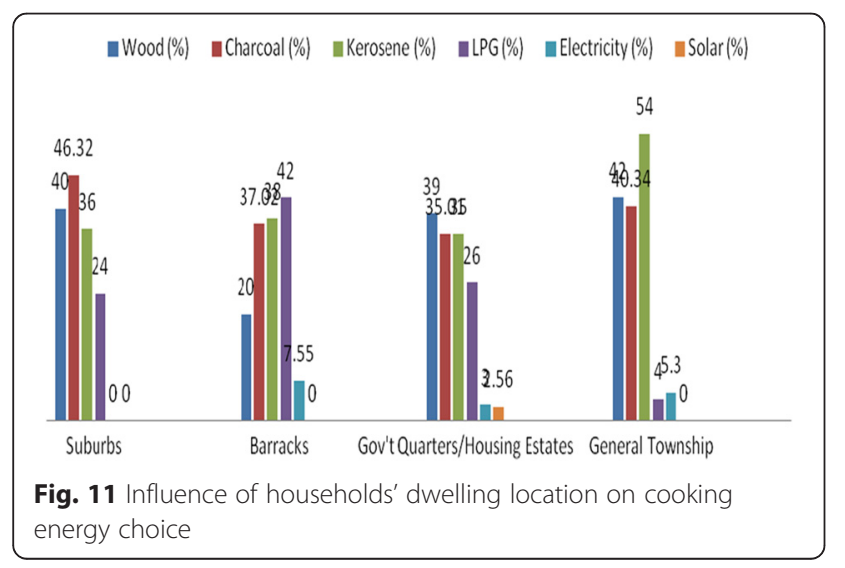

since the rented buildings usually do not have sufficient space for fuel storage. More so, the land lords may restrict fuel use to a range of fuels in order to safe guard their properties. While those in owned dwellings have more freedom to use cheaper, lower fuels, they have no restrictions by way of rules or space to construct external kitchens.

\section{Influence of households' dwelling location on cooking energy choice}

Figure 11 shows the influence of households' dwelling location on their cooking energy choice.

The results show that the households in the barracks have the highest consumption of LPG. The suburbs and general township consume more wood than the remaining locations. Government quarters and housing estates consume more charcoal and kerosene.

\section{Influence of income on cooking energy choice}

Figure 12 shows the relationship between cooking energy choice and the annual income of households. The use of wood dropped gradually with increase in income. Charcoal and kerosene utilization rose gradually and then about the middle income level, begin to decline. LPG, electricity and solar energy utilization increased gradually with increase in income, though with some fluctuations.

\section{Households' improved/advanced cook stove adoption and their awareness of the ills of using traditional cook stoves}

In an attempt to determine the relationship between households' awareness of the ills of using traditional stoves ('awareness'), such as the three-stone open fire and their adoption of improved/advanced cook stoves (ICS/ACS), the result shows that $76 \%$ of the respondents are aware of the problems associated with the use of traditional stoves while $24 \%$ are not. On the other hand, $90 \%$ of the respondents use an ICS/ACS, while $10 \%$ do not. Furthermore, the result of regression analysis shows that there is no significant relationship between ICS/ACS adoption and awareness. This implies that households who adopt an ICS/ACS do it for reasons other than their awareness of the ills of using the traditional stoves.

\section{Relationship between fuel price and consumption rate}

Result of regression analysis shows that for wood, charcoal and kerosene, consumption is significantly related to the price of each fuel type. On the other hand, there is no significant relationship between consumption rate and price for LPG and electricity. This means that while the consumption of wood, charcoal and kerosene is a function of their individual prices, LPG and electricity consumption is independent of price. 


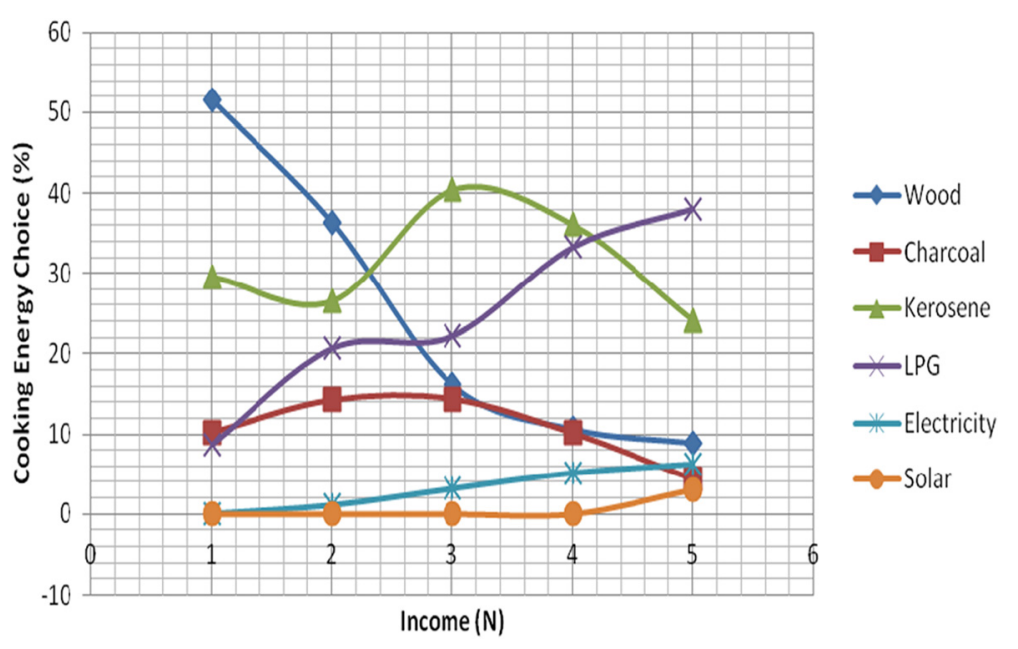

Fig. 12 Influence of income on households' cooking energy choice

\section{Discussion of results}

The results show that although kerosene is predominantly used as a primary cooking fuel, biomass is still being heavily used, while electricity and solar energy are only used as secondary cooking energy. Compared to the results of other studies such as [10] which cover the whole country (Nigeria), there is an improvement in the use of kerosene and LPG for cooking. The heavy use of biomass has resulted in deforestation in all parts of Bauchi state and heavy erosion in some parts, leading to heavy agricultural loses due to the washing away of farm lands and crops. Some major roads, such as the BauchiDass-Tafawa Balewa road, are being threatened by the fast spreading gully erosion by Bayara village. The heavy use of biomass fuels may be as a result of low-income levels as shown in Fig. 1. It is also attributable to the poor availability of electricity resulting from inconsistent supply (Figs. 4 and 5). The increase in the use of kerosene and LPG for cooking is as a result of increased availability due to improvement in relevant infrastructure such as the increase in the number of filling stations which brings the commodities closer to the people and also due to the lack of reliable electricity supply.

The results further show that many of the households use multiple fuels. This may be connected to the fact that some fuels are not always available and seasonal changes are likely to induce change of fuel (Fig. 7). The use of some higher fuels (LPG, electricity and solar) increased with rise in income, while firewood, charcoal and kerosene use declined. This shows that as the income increased, households' economic status improve and are more likely to afford and shift to modern cooking facilities.

Change in household size is one factor that affects wood consumption. Bauchi state is dominated by Islam, which allows the marrying of up to four wives, thereby increasing the tendency of an increase in the size of the family. The culture of the people is such that necessitates maintaining ties with extended relations resulting in visitations especially during festive periods. The resulting increase in family size due to visitations or marrying more wives and the attendant increase in the number of children makes cooking with more expensive higher fuels uneconomical and may necessitate switching to cheaper fuels such as wood, thereby increasing its consumption. Also, personal ownership of a dwelling gives the owner freedom to use any fuel for cooking. More so, they are likely to have more space to construct an external kitchen to accommodate lower fuels such as wood, thereby increasing its consumption.

Wood consumption has however been shown be decrease with change of season, increase in income and level of education of the respondents. This is possible because when the season changes from dry to rainy season, wood becomes difficult to use due to poor burning rate and inefficient combustion resulting from increased moisture content. More so, wood is mostly brought into the metropolis from villages with bad roads that are hardly motorable during the rainy season; this causes a price hike due to scarcity resulting from shortage in supply, forcing the household to go for alternative fuels that are available and more efficient. When the level of education of a person increase, the tendency is to get better jobs with higher income resulting in a movement up the socio-economic ladder. This further results in a desire to use higher or cleaner fuels to suit their new socioeconomic status. This therefore affects wood consumption negatively.

On charcoal consumption, it has been shown in the result that $D l$ and $A v$ are the influential factors. Reference to Fig. 11, more charcoal is consumed in the 
suburbs and the general township than the barracks and government quarters/housing estates. This implies that charcoal consumption will increase if a household relocates from the barracks or government quarters to the suburbs or general township. This is probably because of the restrictions on the free flow of vehicles into the barracks, especially those with bulky and concealed content, owing to the security challenges being experienced currently in the study area, and the nature of the buildings in the barracks and government quarters or housing estates which mostly have internal kitchens with little or no space for keeping bulky fuels. The availability of charcoal usually decreases during the rainy season with attendant price hike due to production and transportation difficulties since it is mostly produced in the villages where the roads are not very good during the rainy season. The increase in price resulting from scarcity will have a negative resultant effect on its consumption.

An increase in availability increases the consumption of kerosene, implying that a reduction in availability probably due to scarcity may cause a price hike, thereby reducing its consumption since price affects it. This means that encouraging kerosene consumption will require increasing the availability of the commodity at low price. Another important factor in kerosene consumption is change of season from dry to rainy season, which results in increased kerosene consumption. This is because wood and charcoal become more difficult and inefficient to use and also expensive due to increased moisture content and scarcity, respectively. Kerosene however is not affected by moisture, and since it is more available, households that cannot afford higher fuels fall back to it.

Household size is significantly related to kerosene consumption. When the number of people in a family increases, the quantity of food to be cooked also increase, making kerosene consumption uneconomical. Therefore, the household is forced to fall back to cheaper, lower fuels. Dwelling ownership status significantly influences the consumption of kerosene by a household. This means that relocating from a rented to household dwelling to a personally owned one reduces kerosene consumption. This is because personal ownership of a dwelling in urban areas means better income and a rise in the socio-economic status of the owner. It also means more space and no restrictions by way of tenancy rules on type of fuel to be used. These give the owner the freedom to shift to other fuels either higher or lower, since they are likely to have more space to store bulky fuels and construct an external kitchen.

In the household, LPG consumption was found to be related negatively with availability and household size and positively with affordability. The relationship with availability is consistent with the finding of [29] who found that the main barrier to gas use in some villages in Pakistan was the lack of availability of the LPG in sufficient quantity to meet the need of the consumers. The situation in Bauchi is that there are few shops for selling LPG, and many consumers have to travel long distance to buy the commodity. More so, the sellers have to buy it from depots located far away from Bauchi. This therefore discourages LPG consumption. On the household size, an increase in the household size translates into the demand for a larger quantity of food to be cooked at a time. This makes the use of gas unattractive because the gas stove available in the market is too small to accommodate very large pots. Insisting on using gas for such large pots may require industrial burners which will definitely consume more gas. Since there are cheaper alternatives, households prefer to go for them, thereby reducing gas consumption.

The positive relationship between LGP consumption and affordability corroborates the finding of [29] and [22], who found cost to be one of the barriers to use gas for cooking in households. Affordability is a function of the consumer's income. Therefore, LGP consumption increased probably due to increasing availability and as more consumers' income increased (Fig. 12) due to more of them getting better paying jobs resulting from increased education (Fig. 9).

The finding that no significant relationship exists between households' and restaurants' awareness of the ills of using traditional fuels and cooking technologies and their rate of adoption of ICS/ACS for cooking is consistent with the findings of [30] who, in a study to investigate the relationship between attitude and actual human behaviour, found that attitudes do not always translate into actual behaviour. This finding was corroborated by [31] who found that electricity consumers who were generally sympathetic to environmental issues did not necessarily adopt green tariffs. This therefore presents the need for more investigation into the factors which influence ICS/ACS adoption. Berger and Corbin [32] have suggested that cultural, socio-economic and situational circumstances are capable of affecting actual human behaviour. Therefore, further research in that direction may yield some desirable result.

\section{Conclusions}

This study focused on household cooking energy choice in Bauchi metropolis, North-east Nigeria. It was based on a survey data generated through the use of a questionnaire personally administered by the researchers and assistants. The results show that biomass is still being used heavily by households as the primary and secondary cooking energy. The use of LPG is seen to be rising, while electricity and solar energy are only used as the secondary cooking energy by very few households. This is as a result of the poor availability of electricity due to epileptic supply. 
The cooking energy consumption patterns follow the fuel stacking model as most households use multiple fuels. However, households transit gradually to higher fuels as income and level of education increase.

The results of the study also show that several factors affect household cooking energy choice. These include change in household size, dwelling ownership status, change of season, income, level of education, dwelling location, availability, and affordability. On the other hand, type of food, taste of food, quantity of food, land lord's rules, ease of use, fastness, scarcity of primary fuel and gender have no significant influence on households' fuel choice.

\section{Recommendations}

The high rate of wood and charcoal consumption has a destructive tendency on the nation's forest resources. One way to reduce this is to make wood and charcoal consumption sustainable by encouraging local communities to have woodlots. The family woodlots will provide the required firewood, while it improves soil fertility.

The government and policymakers should take adequate steps to ensure that all citizens have access to modern, environmentally friendly energy resources and the relevant technologies for their sustainable consumption at affordable costs. The factors which influence energy consumption should be used as a guide. The government should identify and develop clear policy incentives for increased private sector participation in delivery of offgrid power and improved cook stoves.

Evidence of the positive influence of education on modern energy consumption suggests that energy education should be included in the nation's curriculum at least up to the secondary school level, in order to inculcate the idea of responsible and sustainable energy behaviour in the minds of young Nigerians.

The evidence of the influence of location on energy consumption suggests that the supply of electricity and other modern energy sources and appliances should be extended to rural areas. This could increase their consumption and the adoption of green technologies for cooking and activities, thereby reducing pressure on the nation's forest resources. A public-private partnership may be useful in this.

The influence of income and affordability on energy consumption suggests that poverty is a problem mitigating sustainable energy consumption. In order to overcome this, the government should provide incentives for households and businesses which will encourage them to use clean energy sources and motivate them to efficiently use them. This can be achieved through microfinance interventions that will provide credit access to households and businesses to help them acquire technologies for clean energy utilization. Moreover, clean energy technologies such as improved cook stoves can be made cheaper by granting tax holidays/waivers to companies involved in such businesses.

\section{Abbreviations \\ LPG, liquefied petroleum gas (used in this text to represent all cooking gases); ICS/ACS, improved/advanced cook stove.}

\section{Competing interests}

The authors declare that they have no competing interests.

\section{Authors' contributions}

The study was designed by all the three authors. Data collection, collation and analysis were done by DYB. AK supervised the project and drafted the article, and it was proof read and edited by HAl. All authors read and approved the final manuscript.

\section{Acknowledgements}

The authors wish to acknowledge IJEEE and the anonymous reviewers for granting them the opportunity to publish this article. We appreciate the numerous individuals and organizations who have contributed in one way or another towards the successful completion of this publication.

\section{Author details}

${ }^{1}$ Department of mechanical Engineering Technology, Federal Polytechnic, Bauchi, Nigeria. ${ }^{2}$ Department of Mechanical Engineering, Federal University of Agriculture, Makurdi, Nigeria.

Received: 15 October 2015 Accepted: 14 May 2016

Published online: 09 June 2016

\section{References}

1. Saeed SH, Sharma DK (2012) Non-conventional energy resources. KATSON Books, New Delhi

2. Banos R, Manzano-Agugliaro F, Montoya FGC, Alcayde A, Gomez J (2011) Optimization methods applied to renewable and sustainable energy: a review. Renew Sust Energ Rev 15:1753-1766

3. Oyedepo O (2012) Energy and sustainable development in Nigeria: the way forward. Energy Sustain Soc 2:15

4. Chukwu PU, Ibrahim IU, Ojosu JO, lortyer HA (2014) Sustainable energy future for Nigeria: the role of engineers. J Sustain Dev Stud 6(2):242-259

5. Baiyegunhi LJS, Hassan MB (2014) Rural household fuel energy transition: evidence from Giwa LGA Kaduna State, Nigeria. Energy Sustain Dev 20(2014):30-35

6. African Development Bank Group (AFDB) (2014) West Africa monitor quarterly, vol 3., pp 14-15

7. Iwayemi I (2008) Investment in electricity generation and transmission in Nigeria: issues and options. International Association for Energy Economics Newsletter, First Quarter, 2008., pp 37-42

8. Mwampamba TH, Ghilardi A, Sander K, Chaix KJ (2013) Dispelling common misconceptions to improve attitudes and policy outlook on charcoal in developing countries. Energy Sustain Dev 17:75-85

9. Hossain KA (2012) Global energy consumption pattern and GDP. Int J Renew Energy Technol Res 1(1):23-29, ISSN:2325-3924

10. Ogwumike FO, Ozughalu UM, Abiona GA (2014) Household energy use and determinants: evidence from Nigeria. Int J Energy Econ Policy 4(2):248-262

11. WHO (2010) Household air pollution and health. USA: Fact Sheet $N^{\circ} 292$. Available at http://www.who.int/mediacentre/factsheets/fs292/en/

12. Elledge MF, Nandasema S, Philips MJ, Thornburg VE: Environmental health risk and the use of biomass stoves in Sri Lanka. Research Brief, RTI Press

13. WHO (2006) Fuel for Life: Household energy and health. Geneva. Available at http://www.who.int/indoorair/publiactions/fuelforlife.pdf Accessed 20 May 2015

14. Malla S, Timilsina GR (2014) Household cooking fuel choice and adoption of improved cook stoves in developing countries: a review. Policy Research Working Paper 6903. The World Bank Development Research Group; Environment and Energy Team. http://econ.worldbank.org. Accessed 15 Aug 2014

15. Wilson E (2012) Energy equity: can the UN sustainable energy for all initiative make a difference? International Institute for Environment and 
Development, http://www.iied.org/energy-equity-can-un-sustainableenergy-for-all-initiative-make-difference. Accessed 15 June 2014

16. Kichonge B, John GR, Mkilaha ISN, Hameer S (2014) Modelling of future energy demand for Tanzania. J Energy Technol Policy 4(7):16-31

17. Wuyuam P, Zerriffi H, Jihua P (2008) Household level fuel switching in rural Hubei, program on energy and sustainable development. Stanford, Working paper No. 79, August 2008

18. Yu B, Zhang J, Fujiwara A (2012) Analysis of the residential location choice and household energy consumption behaviour by incorporating multiple self-selection effects. Energy Policy 46(2012):319-334

19. Barnes DF, Krutilla K, Hyde W (2005) The urban household energy transition: energy, poverty, and the environment in the developing world. World Bank https://www.esmap.org/sites/esmap.org/files/Rpt_UrbanEnergyTransition. pdf. Accessed 19 Sept 2014

20. Heltberg R: Factors determining household fuel choice in Guatemala, environment and development economics. Shaftesbury Road Cambridge, UK: University Printing House; 10:337-16

21. Farsi M, Fillipini M, Pachauri S (2007) Fuel choices in urban Indian households, environment and development economics. Cambridge University Press 12(06): $757-774$

22. Osiolo, Helen H (2009) Enhancing household fuel choice and substitution in Kenya, Kippra discussion paper no. 102. http://searchworks.stanford.edu/ view/9608349. Accessed 7 Sept 2015

23. Masera O, Saatkanp B, Kammen D (2000) From linear fuel switching to multiple cooking strategies: a critique and alternative to the energy ladder model. World Dev 28(12):2083-2103

24. Risseeuw, Natasha: Household energy in Mozambique: a study on the socio-economic and cultural determinants of stove and fuel transitions. Research Project, IVM Institute for Environmental Studies, http://www.ivm. vu.nl/en/Images/Risseeuw_Natasha___FINAL_THESIS_tcm234-352225.pdf August 2012 Accessed 7 Sept 2015

25. Yonemitsu A, Njenga M, liyama M, Matsushita S (2015) A choice experiment study on fuel preference of Kibera slum households in Kenya. Int J Environ Sci Dev 6;(3):196-200

26. Mekonnen A, Gebre Egziabher Z, Kassie M, Kolin G (2009) Income alone doesn't determine adoption and choice of fuel types: evidence from households in Tigrai and major cities in Ethiopia, environment for development (EFD) policy brief www.environmentfordevelopment.org Accessed 26 July 2014

27. Belk RW (1975) Situational variables and consumer behaviour. J Consum Res 2 https://jcr.oxfordjournals.org/content/jcr/2/3/157.full.pdf

28. Bartiaux F, Gosselain V, Stamova G, Ozolina L, Gara E (2011) Knowledge on climate change and energy saving renovations by apartment owners in Bulgaria and Lavita. A quantitative study. Int Rev Soc Res 1(3):133-154

29. Jan I, Khan H, Hayat S (2012) Determinants of rural household choices: an example from Pakistan. Pol J Environ Stud 21(3):635-641

30. Lapiere RT (1934) Attitudes versus actions. Soc Forces 13(2):230-237

31. Ozaki R, Shaw I (2014) Adoption and use behaviour of consumers of energy-sustainable technologies. Energy Business Research Laboratory, Imperial College, London http://wwwf.imperial.ac.uk/business-school/ research/energy-business-research-laboratory/research/adoption-and-usebehaviour-of-consumers-of-energy-sustainable-technologies/

32. Berger IE, Corbin RM (1992)Percieved Effectiveness and faith in others as moderators of environmentally responsible behaviour. J Pub Policy Mark 11(2):7989 http://www.jstor.org/stable/30000276

\section{Submit your manuscript to a SpringerOpen ${ }^{\circ}$ journal and benefit from:}

- Convenient online submission

- Rigorous peer review

- Immediate publication on acceptance

- Open access: articles freely available online

- High visibility within the field

- Retaining the copyright to your article 